\title{
Evaluation of internal markers as determinants of fecal dry matter output and digestibility in feedlot sheep ${ }^{1}$
}

\section{Avaliação de marcadores internos como determinantes da excreção fecal de matéria seca e da digestibilidade em ovinos confinados}

\author{
Ícaro dos Santos Cabral2; José Augusto Gomes Azevêdo ${ }^{3}$; Douglas dos Santos \\ Pina $^{4}$; Luiz Gustavo Ribeiro Pereira ${ }^{5}$; Flávio Moreira de Almeida ${ }^{6}$; Lígia Lins \\ Souza ${ }^{3}$; Ronaldo Francisco de Lima $^{7}$
}

\begin{abstract}
This study aimed to evaluate the fecal recovery of the internal markers indigestible dry matter (iDM), indigestible neutral detergent fiber (iNDF), and indigestible acid detergent fiber (iADF) and to compare them as estimators of the fecal dry matter output (FDMO) and digestibility of the dry matter (DM) with values observed in total feces collection in trials with feedlot sheep. For this, 82 sampling units from two experiments were evaluated. Internal markers were quantified in the feed supplied, orts, and feces. The recovery of the markers was determined by the comparison of the amount of marker consumed and excreted. Fecal dry matter output and digestibility were determined based on the amount of marker consumed and on its concentration in the feces through individual collections directly from the rectum of the animals, with values compared with those observed in the total feces collection from orthogonal contrasts. The mean bias, the concordance correlation coefficient, and the mean squared prediction error were also evaluated. For all statistical procedures, the critical level of probability for type-I error was fixed at 0.05 . The marker iDM showed complete fecal recovery $(100.03 \%)$ and was efficient in estimating FDMO (482.9 $\left.\mathrm{g} \mathrm{day}^{-1}\right)$ and DM digestibility $\left(542 \mathrm{~g} \mathrm{~kg}^{-1}\right)$ as compared with the values observed in the total feces collection (454.7 $\mathrm{g} \mathrm{day}^{-1}$ and $561 \mathrm{~g} \mathrm{~kg}^{-1}$ for FDMO and DM digestibility, respectively). The iNDF and iADF markers did not show complete recovery in the feces and were not effective in the estimate of FDMO and DM digestibility.
\end{abstract}

Key words: Fecal excretion. Indigestible components. Methodology.

\section{Resumo}

O objetivo deste trabalho foi avaliar a recuperação fecal dos marcadores internos matéria seca indigestível (MSi), fibra em detergente neutro indigestível (FDNi) e fibra em detergente ácido indigestível (FDAi) e compará-los como estimadores da excreção fecal de matéria seca (EFMS) e digestibilidade da matéria seca com os valores observados na coleta total de fezes em ensaios com ovinos confinados. Para isso, foram avaliadas 82 unidades amostrais de dois experimentos. Os indicadores internos foram

1 Parte da tese de Doutorado do primeiro autor, Programa de Pós-Graduação em Zootecnia da UESB, Universidade Estadual do Sudoeste da Bahia.

2 Prof., Universidade Federal do Oeste do Pará, UFOPA, Santarém, PA, UF, Brasil. E-mail: i.s.cabral@hotmail.com

3 Profs., Universidade Estadual de Santa Cruz, UESC, Ilhéus, BA, Brasil; E-mail: zeguto00@gmail.com; ligia_lins@yahoo.com.br

4 Prof., Universidade Federal da Bahia, UFBA, Salvador, BA, Brasil. E-mail: douglaspinaufba@gmail.com

5 Pesquisador, Empresa Brasileira de Pesquisa Agropecuária, EMBRAPA Gado de Leite, Juiz de Fora, MG, Brasil. E-mail: luiz. gustavo@embrapa.br

6 Prof., Centro Universitário de Patos de Minas, UNIPAM, Patos de Minas, MG, Brasil. E-mail: flavioma@unipam.edu.br

Prof., Universidade Federal do Amazonas, UFAM, Parintins, AM, Brasil. E-mail: ronaldofranciscolima@yahoo.com.br

"Author for correspondence 
quantificados no alimento fornecido, sobras e fezes. A recuperação dos marcadores foi determinada pela comparação da quantidade de marcador consumido e excretado. A EFMS e a digestibilidade da matéria seca foram determinadas com base na quantidade de marcador consumido e na sua concentração nas fezes. Os valores preditos com a utilização dos marcadores foram comparados aos observados na coleta total de fezes a partir de contrastes ortogonais. Também foram avaliados o viés médio, o coeficiente de concordância da correlação e o quadrado médio do erro de predição. Para todos os procedimentos estatísticos, o nível crítico de probabilidade para o erro de tipo I foi fixado em 0,05 . O marcador MSi mostrou recuperação fecal completa $(100,03 \%)$ e foi eficiente na estimativa da EFMS $\left(482,9 \mathrm{~g} \mathrm{dia}^{-1}\right) \mathrm{e}$ digestibilidade da MS (542 $\left.\mathrm{g} \mathrm{kg}^{-1}\right)$ em comparação aos valores observados na coleta total de fezes $(454,7$ $\mathrm{g} \mathrm{dia}^{-1}$ e $561 \mathrm{~g} \mathrm{~kg}^{-1}$, respectivamente). Os marcadores FDNi e FDAi não demonstraram recuperação completa nas fezes e não foram eficazes na estimativa da EFMS e digestibilidade da MS.

Palavras-chave: Componentes indigestíveis. Excreção fecal. Metodologia.

\section{Introduction}

The starting point of the estimate of dietary digestibility parameters is obtaining the consumed portion undigested and absorbed during the passage through the gastrointestinal tract, represented naturally by the feces excreted by the animal.

Obtaining estimates of fecal excretion via total feces collection is a costly process that requires strict control of the daily intake and excretion and also that animal adapt to cages and collection bags, causing discomfort and interfering with their behavior, which ultimately makes it an unfeasible practice in situations such as grazing trials. Alternatively, indirect methods have been proposed to estimate digestibility and fecal output parameters, among which is the use of markers that has stood out for advantages over total feces collection like its simplicity and practicality (DETMANN et al., 2007; CABRAL et al., 2008; SAMPAIO et al., 2011; CARVALHO et al., 2013).

A marker consists of a substance or a compound employed for monitoring physical or chemical aspects of digestion. It can be of external (exotic to the diet components) or internal nature (a component of the diet). For a marker to be considered ideal, it must not be absorbed, or it must have constant and known digestibility; it must not affect or be affected by the gastrointestinal tract or its microbial population; it must flow separately or be physically similar or closely linked to the material to be evaluated; and it must have a rapid and precise method of evaluation (DETMANN et al., 2007).

In general, internal markers naturally display some characteristics of ideal markers. Their main features are the non-negative influence on the animal digestive and microbial systems, and separate flow from the evaluated material, as they are natural components of feed. Thus, the determination of the ideal characteristics of markers of this nature should be focused on questions related to their recovery after being subjected to the gastrointestinal tract events (DETMANN et al., 2007).

There are many studies involving the evaluation of these markers, but results are still divergent. Cabral et al. (2008) evaluated the internal markers indigestible neutral detergent fiber (iNDF) and indigestible acid detergent fiber (iADF) obtained in vitro in the determination of the fecal dry matter output (FDMO) and digestibility and concluded that iNDF was precise in the determination of both; the iADF, however, overestimated FDMO and underestimated the digestibility in an experiment with cattle.

In determining FDMO in feedlot sheep, Sampaio et al. (2011) evaluated the internal markers indigestible dry matter (iDM), iNDF, and iADF and concluded that all markers were effective.

In a trial with sheep, Detmann et al. (2007) analyzed only the fecal recovery of the markers iDM, iNDF, and iADF and observed complete 
recovery of the first two, thereby demonstrating their applicability in digestibility trials. However, iADF displayed a larger excretion than the amount ingested by the animal, which made its use impracticable. Vargas (2011), in turn, concluded that iADF was effective and iNDF was ineffective in determining digestibility in sheep.

Analyzing the use of the markers in both sheep and goat, Carvalho et al. (2013) concluded that iDM and iNDF showed complete fecal recovery, whereas iADF had an incomplete recovery.

Given the considerations above, this study aimed to evaluate the fecal recovery of the internal markers iDM, iNDF, and $\mathrm{iADF}$, and to compare the FDMO and DM digestibility values calculated using the markers with those observed in total feces collection in experiments with feedlot sheep.

\section{Material and Methods}

The experiment was carried out in the Laboratory of Animal Nutrition of Universidade Estadual de Santa Cruz (UESC), located in Ilhéus - BA, Brazil.

To evaluate the effectiveness of use of the internal markers, samples of feed supplied, orts, and feces from 18 Santa Inês sheep were used, consisting of eight animals from an experiment with inclusion of cocoa meal in the diet ( 8 animals $\times 4$ periods $=32$ sampling units) and ten animals from an experiment with inclusion of different levels of crude glycerin in the diet (10 animals $\times 5$ periods $=50$ sampling units). Both experiments were conducted in a double Latin square design $(4 \times 4$ and $5 \times 5$ ) in which each period comprised 21 days, with the first 16 used for the adaptation of animals and the last 5 for total feces collection, besides daily collection of feed and orts. Samples were incubated in situ according to the method described by Casali et al. (2008) for determination of the iDM, iNDF, and $\mathrm{iADF}$ contents.
The amount of marker ingested (MI) was obtained by the following formula (SAMPAIO et al., 2011):

$\mathrm{MI}(\mathrm{g})=\left(\mathrm{FS}\left(\mathrm{g} \mathrm{day}^{-1}\right) \times \% \mathrm{M}_{\text {Feed }}\right)-\left(\right.$ Orts $\left(\mathrm{g} \mathrm{day}^{-1}\right)$ $\times \% \mathrm{M}_{\text {Orts }}$,

where FS is the amount of feed supplied; $\mathrm{M}_{\text {Feed }}$ is the marker content in the feed supplied; Orts is the amount of orts; and $\mathrm{M}_{\mathrm{Orts}}$ is the marker content in the orts.

The formula (SAMPAIO et al., 2011) below was used to determine the amount of marker excreted (ME):

$$
\operatorname{ME}(\mathrm{g})=\text { Feces }\left(\mathrm{g} \mathrm{day}^{-1}\right) \times \% \mathrm{M}_{\text {Feces }},
$$

where Feces is the amount of feces obtained in the total collection and $\mathrm{M}_{\text {Feces }}$ is the marker content in the feces

Fecal recovery (FRC) was determined by the following formula (SAMPAIO et al., 2011):

$$
\operatorname{FRC}(\%)=\frac{\operatorname{ME}\left(\mathrm{g} \mathrm{day}^{1}\right)}{\mathrm{MI}\left(\mathrm{g} \mathrm{day}^{1}\right)} * 100
$$

The FDMO and the DM digestibility (DMD) were estimated from each marker using the following formulae (SAMPAIO et al., 2011):

$$
\operatorname{FDMO}(\mathrm{g} / \text { day })=\frac{\text { MI }\left(\text { g day }^{-1}\right)}{(\% \text { MFeces } / 100)}
$$

and

$$
\left.\operatorname{DMD}(\%)=\frac{\left(\mathrm{DMI}\left(\mathrm{g} \mathrm{day}-{ }^{1}\right)-\mathrm{FDMO}\left(\mathrm{g} \mathrm{day}-{ }^{1}\right)\right.}{\mathrm{DMI}\left(\mathrm{g} \text { day }-{ }^{1}\right)}\right) * 100
$$

The fecal output and apparent digestibility of the dry matter obtained by using the markers were compared with the data observed in the total feces collection.

To evaluate the recovery of the markers, an analysis of variance was performed to compare the amounts ingested and excreted of each marker.

The fecal excretion and digestibility estimated with the use of the markers were evaluated by the decomposition of the sum of squares by orthogonal contrasts (Table 1). 
Table 1. Distribution of the coefficients in the orthogonal contrasts employed in the decomposition of the sum of squares.

\begin{tabular}{lcccc}
\hline Contrast & TFC & iDM & iNDF & iADF \\
\hline A & +1 & -1 & 0 & 0 \\
B & +1 & 0 & -1 & 0 \\
C & +1 & 0 & 0 & -1 \\
\hline
\end{tabular}

TFC - total feces collection; iDM - indigestible dry matter; iNDF - indigestible neutral detergent fiber; iADF - indigestibles acid detergente fiber

Contrast A: TFC vs. iDM; Contrast B: TFC vs. iNDF; Contrast C: TFC vs. iADF.

The contrasts were made to compare the values obtained with the total feces collection in relation to the markers iDM (contrast A), iNDF (contrast B), and $\mathrm{AADF}$ (contrast $\mathrm{C}$ ). The analysis of variance and the orthogonal contrasts were performed on SAS software (2001), adopting 0.05 as the critical level of probability for type-I error.

The mean bias (MB) was calculated according Cochran and Cox (1957), using the equation below:

$$
M B=\frac{1}{n} \sum_{i=1}^{n}(x i-y i)
$$

Where: $\mathrm{x}=$ observed values; $\mathrm{y}=$ predicted values.

The concordance correlation coefficient (CCC), also known as reproducibility index, which considers exactness and precision simultaneously, was calculated according to Lin (1989).

The comparative evaluation of the efficiency of prediction of the equations was undertaken by analyzing the mean squared prediction error (MSPE), as described by Bibby and Toutenburg (1977), according to the equation below:

$$
M S P E=\frac{1}{n} \sum_{i=1}^{n}(x i-y i)^{2}
$$

Where: $\mathrm{x}=$ observed values; $\mathrm{y}=$ predicted values.

Model Evaluation System (MES) software version 3.0.11 (http://nutritionmodels.tamu.edu/ mes.htm, College Station, TX, USA; TEDESCHI,
2006) was used for the evaluation of MB, CCC, and MSPE.

\section{Results and Discussion}

In the evaluation of the results for the fecal recovery of the markers (Table 2), it was found that only the marker iDM showed the same excretion and intake $(\mathrm{P}>0.05)$.

Only the marker iDM did not differ $(\mathrm{P}>0.05)$ in the analysis of variance. Therefore, the marker excretion values are similar to the marker ingestion values.

Based on the analysis of variance, it was observed that the marker iDM showed complete fecal recovery, i.e., the amount ingested did not differ $(\mathrm{P}>0.05)$ from the amount excreted. The result of the evaluation of the markers iNDF and iADF was different $(\mathrm{P}<0.05)$, indicating the low precision of these markers and demonstrating the underestimate of fecal recovery; in other words, the excreted amount was lower than the ingested amount, thus preventing its use as an estimator of FDMO and digestibility. The incomplete recovery may be a result of the accumulation of methodological errors, given that the method of determination of iNDF and iADF is sequential and obtained after determining iDM. The literature also reports that because of the lower concentration of $\mathrm{iADF}$ as compared with iDM and iNDF in the feedstuffs, the reliability of the analysis is compromised (DETMANN et al., 2004). 
Table 2. Means and P-value of the ANOVA of intake and excretion values of the internal markers indigestible dry matter (iDM), indigestible neutral detergent fiber (iNDF), and indigestible acid detergent fiber (iADF).

\begin{tabular}{lccc}
\hline \multirow{2}{*}{ Item } & \multicolumn{3}{c}{ Marker } \\
\cline { 2 - 4 } & iDM & iNDF & iADF \\
\hline Ingested $\left(\mathrm{g} \mathrm{day}^{-1}\right)$ & 283.24 & 260.41 & 202.58 \\
Excreted $\left(\mathrm{g} \mathrm{day}^{-1}\right)$ & 268.38 & 225.69 & 168.95 \\
P-value $^{\mathrm{a}}$ & 0.410 & 0.020 & 0.008 \\
$\mathrm{R}^{2}$ & 0.746 & 0.688 & 0.672 \\
\hline
\end{tabular}

${ }^{\mathrm{a}}$ Analysis of variance.

Carvalho et al. (2013) observed total recovery of the markers iDM and iNDF and incomplete recovery of iADF, in both sheep and goat, contrasting the present experiment as regards iNDF.

Other experiments have shown results partially similar to those found in the present study. Detmann et al. (2007) observed complete recovery of iDM in a study with sheep consuming coast cross (Cynodon dactilon) hay and a concentrate based on corn and soybean meal. These authors also observed complete recovery of iNDF. Sampaio et al. (2011), however, in an experiment with cattle, observed complete recovery of the marker iDM, in addition to iNDF and $\mathrm{iADF}$, which was not found in the present study.

The abovementioned studies (DETMANN et al., 2007; SAMPAIO et al., 2011; CARVALHO et al., 2013) had conclusions about the effectiveness of the markers based on the evaluation of their fecal recovery and the "long-term bias", which is defined as a marker's ability to be excreted in a similar amount to that consumed, in this regard, an effective marker should preset zero "long-term bias" (DETMANN et al., 2007). Apparently, various conditions are associated with the total recovery or not of the internal markers in these trials; for example, the type of diet (ingredients and nutrient content), analytical methods (particle size, filtration system, incubation time, condition of the animals used during the in situ incubation), among others.
In this study, in addition to the fecal recovery of the marker, the effectiveness of the markers in determining FDMO was also evaluated and the same behavior was observed, in which the values calculated with the use of the marker iDM were similar $(\mathrm{P}>0.05)$ and those calculated with the use of iNDF or iADF were different $(\mathrm{P}<0.05)$ from the values observed in the total feces collection. Because the digestibility is estimated from FDMO, a difference was also observed between the digestibility estimate obtained from total feces collection and between the markers iNDF and iADF. When the FDMO is overestimated, the DM digestibility value is underestimated, because if fecal excretion is higher, the amount retained (digested and absorbed) by the gastrointestinal tract will be lower.

The marker iDM was the only one able to precisely estimate the FDMO observed in the total feces collection (Table 3 ). 
Table 3. Mean values for fecal dry matter output (FDMO), coefficients of variation, estimates of regression parameters, and P-values of orthogonal contrasts associated with the values obtained via total feces collection and with the use of the internal markers indigestible dry matter (iDM), indigestible neutral detergent fiber (iNDF), and indigestible acid detergent fiber (iADF).

\begin{tabular}{lcccc}
\hline \multirow{2}{*}{ Item } & & \multicolumn{3}{c}{ Marker } \\
\cline { 3 - 5 } & Total collection & iDM & iNDF & iADF \\
\hline${\text { FDMO }\left(\mathrm{g} \mathrm{day}^{-1}\right)}^{\text {Coefficient of variation (\%) }}$ & 453.67 & 482.90 & 530.69 & 565.71 \\
P-value $^{\mathrm{a}}$ & 28.22 & 37.52 & 35.38 & 31.56 \\
$\mathrm{R}^{2}$ & & 0.197 & 0.002 & $<0.001$ \\
Mean bias & 0.645 & 0.606 & 0.420 \\
$\mathrm{CCC}^{\mathrm{b}}$ & -25.384 & -73.133 & -108.154 \\
MSPE $^{\mathrm{c}}$ & & 0.744 & 0.655 & 0.494 \\
\hline
\end{tabular}

${ }^{\text {a }}$ Contrast A: TFC vs. iDM; Contrast B: TFC vs. iNDF; Contrast C: TFC vs. iADF

${ }^{\mathrm{b}}$ Concordance correlation coefficient

${ }^{\mathrm{c}}$ Mean squared prediction error.

The only marker that did not show differences $(\mathrm{P}>0.05)$ between the estimated fecal output values and those observed in the total feces collection was iDM (contrast A). This marker also showed higher $\mathrm{R}^{2}$ (0.645) and CCC (0.744), a MB (-25.384) closer to 0, and a lower MSPE (12952.931) than the others, suggesting that it is the most suitable for the estimate of FDMO. Despite having a difference $(\mathrm{P}<0.05)$ in relation to the total feces collection, the marker iNDF (contrast B), based on the observation of the $\mathrm{R}^{2}, \mathrm{CCC}, \mathrm{MB}$, and MSPE values, showed to be more adequate than $\mathrm{ADDF}$ for the same estimate.

In evaluating the DM digestibility values, the marker iDM precisely estimated the values observed in the total feces collection (Table 4).
Once again, only the marker iDM (contrast A) did not show a difference $(\mathrm{P}>0.05)$ between the digestibility values estimated and those calculated via total feces collection. The iDM showed higher $\mathrm{R}^{2}$ (0.732) and CCC (0.744), a MB (1.844) closer to 0 , and a lower MSPE (102.121) than the other markers, thus being the most suitable to estimate digestibility. Despite the difference $(\mathrm{P}<0.05)$ in relation to the total feces collection, the marker iNDF (contrast B), based on the $\mathrm{R}^{2}, \mathrm{CCC}, \mathrm{MB}$, and MSPE values, showed to be more adequate than iADF for the same estimate. 
Table 4. Mean values for DM digestibility, coefficients of variation, estimates of regression parameters, and P-values of orthogonal contrasts associated with the values obtained with total feces collection and with the use of the internal markers indigestible dry matter (iDM), indigestible neutral detergent fiber (iNDF), and indigestible acid detergent fiber (iADF).

\begin{tabular}{lcccc}
\hline \multirow{2}{*}{ Item } & & \multicolumn{3}{c}{ Marker } \\
\cline { 3 - 5 } & Total collection & iDM & iNDF & iADF \\
\hline DM digestibility $\left(\mathrm{g} \mathrm{kg}^{-1} \mathrm{DM}\right)$ & 560.75 & 542.24 & 497.51 & 469.44 \\
Coefficient of variation (\%) $^{26.06}$ & 34.97 & 39.69 & 36.24 \\
P-value $^{\mathrm{a}}$ & & 0.316 & 0.010 & 0.001 \\
$\mathrm{R}^{2}$ & & 0.732 & 0.692 & 0.548 \\
Mean bias & & 18.44 & 63.21 & 91.35 \\
$\mathrm{CCC}^{\mathrm{b}}$ & & 0.823 & 0.747 & 0.629 \\
MSPE $^{\mathrm{c}}$ & & 102.121 & 163.268 & 218.084 \\
\hline
\end{tabular}

${ }^{a}$ Contrast A: TFC vs. iDM; Contrast B: TFC vs. iNDF; Contrast C: TFC vs. iADF

${ }^{\mathrm{b}}$ Concordance correlation coefficient

${ }^{\mathrm{c}}$ Mean squared prediction error.

The literature is controversial when it comes to the use of internal markers. For instance, Cabral et al. (2008) observed that iNDF was effective in determining the FDMO and DM digestibility in cattle fed corn silage, Tifton-85 grass hay and elephant-grass silage; iADF, in turn, was effective in determining the analyzed variables only when the animals consumed the corn or elephant-grass silages, but was ineffective when the hay was used.

Ferreira et al. (2009) observed different results in two experiments. In experiment 1 , using crossbred heifers fed sugarcane + urea, iNDF was effective in determining the digestibility of DM, while iADF underestimated this variable. In experiment 2, however, using lactating cows fed corn silage and 4 $\mathrm{kg}$ concentrate per day, iADF had a precise estimate, whereas iNDF overestimated the DM digestibility.

Evaluating data and samples from six independent experiments with sheep fed different feedstuffs in each experiment (hays of Kikuyu grass [Pennisetum clandestinum], Barnyard grass [Echinochloa sp.] and Tifton 85 grass [Cynodon sp.], with and without the presence of several supplements), Kozloski et al. (2009) observed recovery closer to $100 \%$ of the marker iDM compare with the marker iNDF.
However, when the digestibility of the dry matter was estimated with the markers compared with the value observed in the total feces collection, the iDM underestimated results in four out of six experiments, whereas iNDF underestimated digestibility in all experiments.

Vargas (2011) utilized Guinea grass (Panicum maximum) in sheep feeding and concluded that $\mathrm{iADF}$ was effective in determining the DM digestibility, while iNDF underestimated this variable.

Lee and Hristov (2013) supplied two levels of crude protein $(\mathrm{CP})$ to lactating Holstein cows and observed that the marker iNDF underestimated FDMO and consequently overestimated the digestibility of DM when the diet contained a high $\mathrm{CP}$ content. In the diets with low $\mathrm{CP}$, however, the response was the opposite, with iNDF overestimating FDMO and underestimating DM digestibility, all of them relatively to the values observed in the total feces collection.

Because they depend on the value of FDMO, the same factors of variation mentioned above such as types of diets and analytical methods, will also be present in the determination of digestibility through the use of internal indicators. 
The results of this study showed that iDM was only the marker to be completely recovered in the feces and that precisely estimated the FDMO and DM digestibility values.

\section{Conclusions}

The internal markers iNDF and iADF show incomplete fecal recovery, thereby preventing their use as estimators of FDMO and DM digestibility in experiments with feedlot sheep.

The internal marker iDM is completely recovered in the feces and is able to precisely estimate FDMO and DM digestibility values in experiments with feedlot sheep.

\section{Acknowledgements}

The authors acknowledge the support by Fundação de Amparo à Pesquisa do Estado da Bahia, Universidade Estadual de Santa Cruz, Universidade Estadual do Sudoeste da Bahia and Instituto Nacional de Ciência e Tecnologia de Ciência Animal - INCT-CA.

\section{References}

BIBBY, J.; TOUTENBURG, H. Prediction and improved estimation in linear models. New York: J. Wiley and Sons, 1977.

CABRAL, L. S.; VALADARES FILHO, S. C.; DETMANN, E.; ZERVOUDAKIS, J. T.; SOUZA, A. L.; VELOSO, R. G. Avaliação de indicadores na estimação da excreção fecal e da digestibilidade em ruminantes. Revista Brasileira de Saúde e Produção Animal, Salvador, v. 9, n. 1, p. 29-34, 2008.

CARVAlHO, G. G. P.; GARCIA, R.; PIRES, A. G. V.; SILVA, R. R.; DETMANN, E.; OLIVEIRA, R. L.; RIBEIRO, L. S. O. Long-term bias of internal markers in sheep and goat digestion trials. Asian-Australasian Journal of Animal Science, Seoul, v. 26, n. 1, p. 65-71, 2013.

CASALI, A. O.; DETMANN, E.; VALADARES FILHO, S. C.; PEREIRA, J. C.; HENRIQUES, L. T.; FREITAS, S. G.; PAULINO, M. F. Influência do tempo de incubação e do tamanho de partículas sobre os teores de compostos indigestíveis em alimentos e fezes bovinas obtidos por procedimentos in situ. Revista Brasileira de Zootecnia, Viçosa, v. 37, n. 2, p. 335-342, 2008.

COCHRAN, W. G.; COX, G. M. Experimental design. John Wiley \& Sons, New York, 1957.

DETMANN, E.; SOUZA, A. L.; GARCIA, R.; VALADARES FILHO, S. C.; CABRAL, L. S.; ZERVOUDAKIS, J. T. Avaliação do vício de tempo longo de indicadores internos em ensaio de digestão com ruminantes. Arquivo Brasileiro de Medicina Veterinária e Zootecnia, Belo Horizonte, v. 59, n. 1, p. 182-188, 2007.

DETMANN, E.; VALADARES FILHO, S. C.; PAULINO, M. F.; ZERVOUDAKIS, J. T.; CABRAL, L. S. Avaliação da técnica dos indicadores na estimação do consumo por ruminantes em pastejo. Cadernos Técnicos de Veterinária e Zootecnia, Belo Horizonte, v. 45, n. 1, p. 40-57, 2004.

FERREIRA, M. A.; VALADARES FILHO, S. C.; MARCONDES, M. I.; PAIXÃO, M. L.; PAULINO, M. F.; VALADARES, R. F. D. Avaliação de indicadores em estudos com ruminantes: digestibilidade. Revista Brasileira de Zootecnia, Viçosa, v. 38, n. 8, p. 15681573, 2009.

KOZLOSKI, G. V.; MESQUITA, F. R.; ALVES, T. P.; CASTAGNinO, D. S.; STEFANELlO, C. M.; SANCHEZ, L. M. B. Avaliação do uso de frações indigestíveis do alimento como indicadores internos de digestibilidade em ovinos. Revista Brasileira de Zootecnia, Viçosa, v. 38, n. 9, p. 1819-1823, 2009.

LEE, C.; HRISTOV, A. N. Short communication: evaluation of acid-insoluble ash and indigestible neutral detergent fiber as total-tract digestibility markers in dairy cows fed corn silage-based diets. Journal of Dairy Science, Champaign, v. 96, n. 8, p. 5295-5299, 2013.

LIN, L. A. Concordance correlation coefficient to evaluate reprodutibility. Biometrics, Arlington, v. 45, n. 1, p. 255-268, 1989.

STATISTICAL ANALYSIS SYSTEM - SAS. System for Microsoft Windows: release 8.2. Cary: SAS Institute, 2001. CD-ROM.

SAMPAIO, C. B.; DETMANN, E.; VALENTE, T. N. P.; SOUZA, M.A.; VALADARES FILHO, S. C.; PAULINO, M. F. Evaluation of fecal recovering and long term bias of internal and external markers in a digestion assay with cattle. Revista Brasileira de Zootecnia, Viçosa, v. 40, n. 1, p. 174-182, 2011. 
TEDESCHI, L. O. Assessment of the adequacy of mathematical models. Agriculture System, Ithaca, v. 89, n. 2-3, p. 225-247, 2006.

VARGAS, J. H. D. Comparación de los marcadores internos: fibra en detergente neutro (FDNi) y ácido (FDAi) indigestibles y colecta total de heces para estimar la digestibilidad en ovinos de pelo. Revista Colombiana de Ciencia Animal, Sincelejo, v. 4, n. 1, p. 53-70, 2011. 
